8

\title{
St Lucia
}

St Lucia is a small Caribbean island state with real per capita GDP (PPP-adjusted) of US $\$ 5,700$ and total population of about 160,000 people in 2005. As in other countries of the Organisation of Eastern Caribbean States (OECS), the share of services in GDP and trade is high and has increased over time (Charts 8.1 and 8.2).

The service sector drives the St Lucian economy. Some will argue that when tourism is taken out, St Lucia is not a service-driven economy (at least in terms of exports). However, there is already some evidence on the emergence of new service sectors. It is also good to realise that support services and tourism services now depend on one another, so that the growth in tourism depends on support services and vice versa.

St Lucia is at a critical juncture. It needs to diversify into services and knowledge based industries because of the intensification in competition with bigger countries such as Brazil, India and China due to lower tariffs worldwide and preference erosion. However, if it wants to move strongly into services trade beyond tourism, it needs to provide the emerging sectors with at least the same level of support and strategic direction as it did with tourism. In what follows, we will discuss the performance of selected service sectors, identify key factors and challenges behind the performance so far, and then discuss the institutional framework behind the development of trade in services.

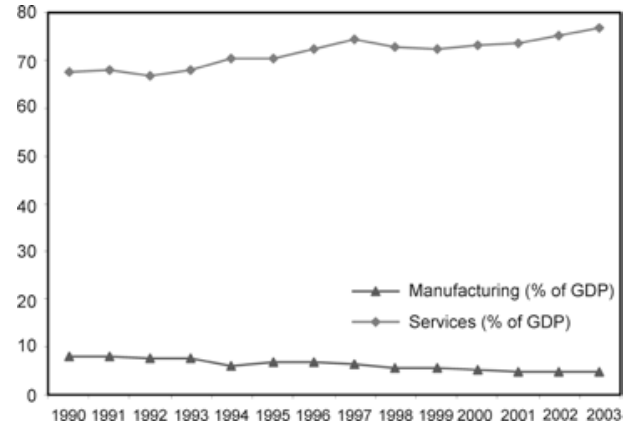

Chart 8.1: Share of services in GDP (\%)

Source: Based on World Bank (2006)

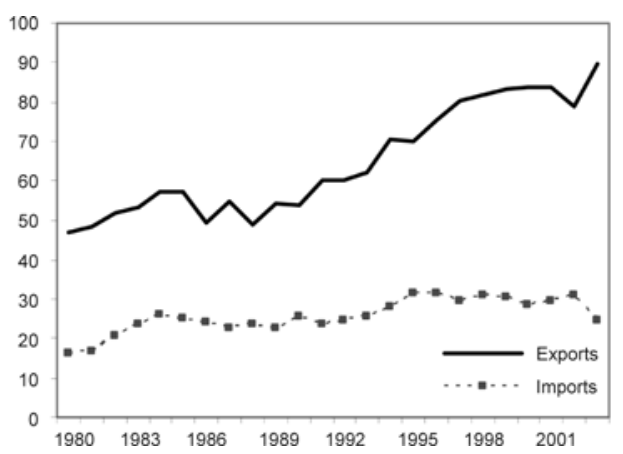

Chart 8.2: Services as \% of all trade 


\section{Performance of selected services}

\section{Financial services}

The financial services sector is responsible for more than 10 per cent of GDP. There are seven commercial banks, four of which are foreign owned. Various foreign-owned insurance companies are also present in the country. Domestically, the sector has been very buoyant over the last few years, with growth rates twice that of the economy as a whole.

However, as indicated by Chart 8.3, the export capacity of the sector seems limited. While the share of offshore financial services in exports of services in Barbados and other OECS countries was as high as 10 per cent in the 1990s, it was much lower in St Lucia where there are very few licensed offshore companies. The limited impact of the financial services sector is argued to be the result of St Lucia's late entry into the offshore sector. For example, whereas the Bahamas began to offer offshore financial services in 1936, Antigua and Barbados in the 1980s, and Belize and St Kitts in the 1990s, St Lucia entered the offshore sector relatively recently in 2000.

\section{Educational services}

The Sir Arthur Lewis Community College (SALCC) was established in St Lucia in 1985 to offer instruction in agriculture, arts, science and general studies, health science, teacher education and educational administration, and technical education and

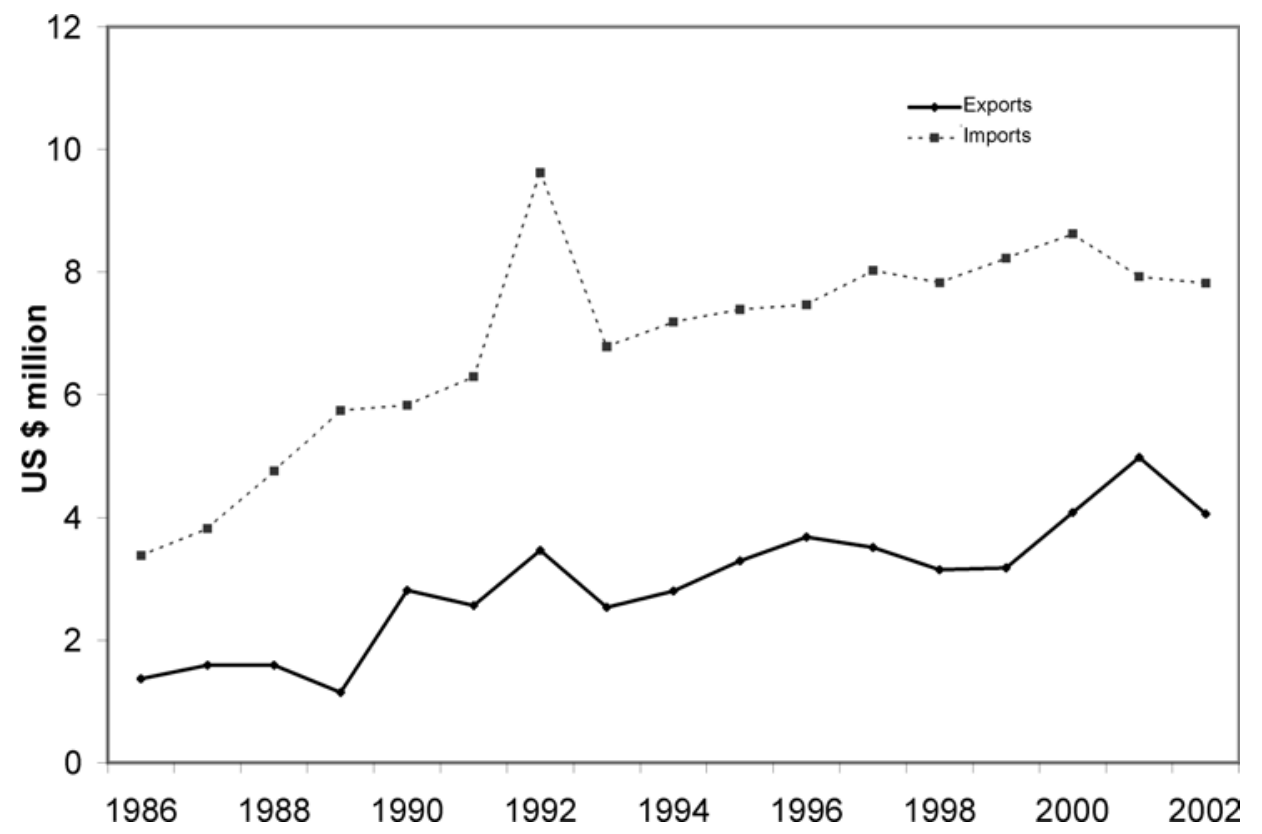

Chart 8.3: Export and imports of insurance services in St Lucia, 1986-2002

Source: UNCTAD (2007) 
management studies. The SALCC does not offer a full university degree, for which students need to go to other universities in the region such as the University of the West Indies (UWI).

However, there are a few offshore medical schools in St Lucia. The best known is the Spartan Health Sciences University School of Medicine, which was founded in 1980 and consists of 13 permanent staff members. The cost of tuition is around US $\$ 3,550$ per trimester for the basic sciences and the clinical sciences programme. The main target market for this institution is the United States. Other medical education institutions include the College of Medicine and Health Sciences (St Lucia) Ltd, which was set up in 2001 and operates in Rodney Bay, and the International American University, which was set up in 2003 and operates in Vieux Fort. Offshore schools contribute to the export of educational services and government revenue by paying a licence fee and an amount per student.

\section{Tourism}

The share of travel exports in total trade of services in St Lucia has been in the range of 80-90 per cent over the last decade and a half, and 20-25 per cent for imports. The tourism sector has increased rapidly over the years, with a doubling of stay-over arrivals and visitor expenditure in the past 15 years (Table 8.1). Capacity has increased at the

Table 8.1: Selected indicators of tourism for St Lucia, 1991-2006

\begin{tabular}{lccccc}
\hline & Total arrivals & $\begin{array}{c}\text { Visitor } \\
\text { arrivals }\end{array}$ & $\begin{array}{c}\text { Hotel } \\
\text { occupancy }(\%)\end{array}$ & $\begin{array}{c}\text { No. of rooms } \\
\text { available }\end{array}$ & $\begin{array}{c}\text { Visitor } \\
\text { expenditure (US\$) }\end{array}$ \\
\hline 1991 & 318,768 & 165,987 & 65.9 & 2,464 & 173 \\
1992 & 348,869 & 183,937 & 73.7 & 2,659 & 209 \\
1993 & 355,259 & 200,886 & 67.9 & 2,919 & 217 \\
1994 & 395,410 & 223,872 & 71 & 2,954 & 225 \\
1995 & 406,454 & 236,883 & 73.2 & 3,974 & 265 \\
1996 & 421,746 & 241,232 & 66.6 & 3,986 & 269 \\
1997 & 563,632 & 253,369 & 71.4 & 4,014 & 284 \\
1998 & 629,598 & 257,530 & 75.3 & 4,077 & 283 \\
1999 & 621,001 & 269,768 & 72.5 & 4,125 & 274 \\
2000 & 726,254 & 282,703 & 67 & 4,428 & 279 \\
2001 & 746,466 & 256,554 & 57 & 4,428 & 233 \\
2002 & 648,364 & 261,184 & 56.1 & 4,428 & 210 \\
2003 & 683,005 & 289,765 & 61.9 & 3,749 & 282 \\
2004 & 791,151 & 309,872 & 68.7 & 3,974 & 326 \\
$2005^{*}$ & 719,844 & 325,480 & 64.8 & 4,556 & 356 \\
$2006^{*}$ & 669,154 & 309,561 & 64.9 & 4,737 & 284 \\
\hline
\end{tabular}

Note: ${ }^{*}=$ provisional.

Source: St Lucia Tourist Board 
same rate, so that occupancy rates in the hotels have not changed dramatically. The estimates by the St Lucia Tourist Board suggest room capacity will sharply increase from 4,800 in 2006 to 8,000 in 2009 as a result of planned investments. The investors in this capacity increase include big brand hotels with their own marketing networks.

A large share of tourism revenues comes from events such as the St Lucia Jazz festival or the Carnival, which have emerged as major international festivals (see Box 8.1). The expenditure during St Lucia Jazz contributed to 8 per cent of the total tourism expenditure in St Lucia in 2006.

\section{Transport, communications and information technology}

St Lucia has a few IT-enabled exporting firms. For example, Helen IT Systems has operated a call centre since 2001 and currently employs around 300 people. Some new call centres opened up in recent years and others closed down. St Lucia has also attracted investment in the ICT sector, for example, Avantext (St Lucia) Ltd in Gros Islet and 'e-Services Group' in Castries.

No separate statistics are available for the exports of IT-enabled services, but the combined share of exports of computer, communications and other services in commercial service exports was about 9 per cent in 2002. The share of exports of transport services in commercial service exports was about 28 per cent in 2002 (Table 8.2). Overall, St Lucia is a net importer of both IT-enabled services as well as transport services.

Box 8.1: Event tourism in St Lucia

St Lucia has built up a basic institutional infrastructure to organise large events such as the Carnival and the Jazz festival with cultural inputs to attract visitors. The St Lucia Jazz festival has become an internationally-recognised event since its establishment in 1991. The festival emerged from the idea to market the country during the low tourist season. It apparently failed to attract many visitors the first time, but renewed efforts helped to make the ten-day event a success. The St Lucia Tourist Board is responsible for the organisation of the festival, whereas its costs are covered by merchandising, gate receipts, and contributions by the St Lucia Tourist Board and the government (for example, duty exemptions for items imported for the festival).

St Lucia Jazz was responsible for 8 per cent of visitor expenditure in 2006 and around 2 per cent of all visitors. Most visitors are from the US, Canada, the UK and the Caribbean. However, there was a sharp drop in visitors in 2007 because of the Cricket World Cup, more expensive airfares and weaker marketing.

The St Lucia Carnival is organised by the Cultural Development Foundation. The carnival emerged in 1948 when the first steel band was imported from Trinidad and Tobago. The World Carnival Conference led to the signature of accords to increase co-operation across countries. In order to prevent a clash of dates with other carnivals (for example, the famous carnival in Trinidad and Tobago), the event was changed permanently to July. There are agreements with neighbouring countries to participate in each other's carnivals so as to attract more tourists. Regional and international recognition of the St Lucia Carnival is growing and it attracted 2,098 tourists (0.3 per cent of all visitors) in 2003. 
Table 8.2: Computer and transport services in St Lucia (\% of service exports)

\begin{tabular}{lcc}
\hline Year & Exports of transport services & Exports of computer, communications and other services \\
\hline 1990 & 10.31 & 21.44 \\
1991 & 12.01 & 30.16 \\
1992 & 11.68 & 29.26 \\
1993 & 13.67 & 26.19 \\
1994 & 14.54 & 27.31 \\
1995 & 14.76 & 24.87 \\
1996 & 11.64 & 23.05 \\
1997 & 10.61 & 23.29 \\
1998 & 20.79 & 18.77 \\
1999 & 22.06 & 23.61 \\
2000 & 24.28 & 21.56 \\
2001 & 23.59 & 28.21 \\
2002 & 27.97 & 8.47 \\
Average & 16.76 & 23.55 \\
\hline
\end{tabular}

Notes: Transport services covers all transport services performed by residents of one economy for those of another and involving the carriage of passengers, movement of goods (freight), rental of carriers with crew and related support and auxiliary services.

Source: UNCTAD (2005)

\section{Professional business services}

It is nearly impossible to get a clear picture of the exports of professional services since such data are difficult to obtain. However, the available data suggests that St Lucia is a net importer of such services, although the exports of these services have increased from almost nil to about 5 per cent of total trade in services (Chart 8.4).

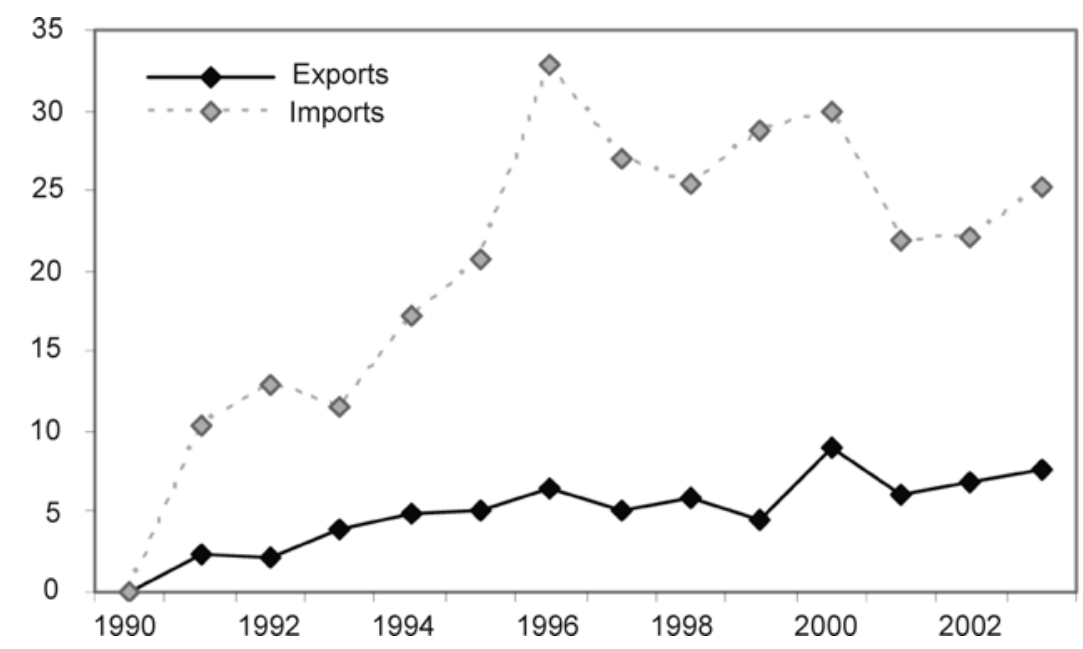

Chart 8.4: Trade in other business services in St Lucia (\% of total trade in services) Source: UNCTAD (2005) 


\section{Supporting factors}

The evolution of St Lucia's services sectors provides some important examples of factors that can support trade in services.

\section{Domestic capabilities}

Box 8.2 discusses factors behind the growth of tourism services. While private interests were the initial driving force behind tourism activity, the government has backed it in various ways. For example, the government was an active supporter of development of the north of the island, paving the way for further tourism.

The general perception in St Lucia is that there is a skills mismatch between the education and training courses and degrees offered and what is needed for the development of the services sectors. While the main call centre may initially not have had difficulties recruiting (good Spanish and English language skills are available), the situation is entirely different if many more call centres came to St Lucia or for more advanced IT jobs such as software development. The education system is not geared towards such sectors. A major problem is the lack of specialised and high-value-added skills. With a need to move up the value chain, the tertiary education sector needs to be developed. A special challenge for a small country such as St Lucia is that it is difficult to move into education and training of all sectors, so a selective approach is almost necessary.

\footnotetext{
Box 8.2: The emergence of tourism in St Lucia

There are various views on what caused the emergence of the tourism industry in St Lucia, but there is a consensus that government played a useful role over the years, including the proactive use of infrastructure. Public-sector representatives point to the commercial interests of individuals in setting up hotels in the 1970s as the kick-starter of the tourism industry. Some significant government support for tourism came later - for example, marketing budgets have increased markedly over the past decade.

Private sector representatives are quick to point out that the government (with development finance support and private entities) played a useful role in developing the north of the island in the 1970s, where most hotels are currently located, reinforcing the importance of tourism. This involved the provision of infrastructure such as the Pigeon Island Causeway, which paved the way for more hotels, and the initial development of Rodney Bay Marina (by a self-made millionaire), leading to a US $\$ 50$ million a year yachting sector.

Reynolds (2003) argues that before 1965 there was no tourism industry, but with a government willing to go to great lengths (generous incentives and access to the best beaches), to set the tourism sector off in order to reduce the dependence on bananas (and sugar before that). Lots of new hotels were built, fuelling a construction boom. Tourism is now more than four times the size of the banana sector.

Source: Interviews in St Lucia; Reynolds, Anderson (2003) The Struggle for Survival: An Historical, Political, and Socioeconomic Perspective of St Lucia
} 
A particular current interest of the government is to develop information and communications technology (ICT) parks. Just as the development of tourism required an integral approach in St Lucia, developing ICT parks and services Export Processing Zones (EPZs) requires a lot of integral planning, as shown by the experience of other small states, such as Ireland, Singapore and Dubai. One key ingredient to the approach will be appropriate human resource development, so that St Lucia can compete with other players in the global economy. Thus, if the government takes ICT initiatives seriously, it would need to upgrade the local tertiary education institute into a full university and offer appropriate courses on ICT as well.

In addition, St Lucia's government would need to further develop the ICT infrastructure. For example, new call centres may not be able to afford a direct fibre cable that allows communication with few delays, and may need to acquire satellites first. Table 8.3 shows that the ICT indicators for St Lucia are no worse that the regional averages. In fact they are better in terms of access to ICT, indicating that St Lucia has a certain base on which it can build its ICT infrastructure further.

\section{Policy and institutional framework}

In terms of overall performance, governance in St Lucia according to 2005 World Bank governance indicators, appears to be better than an average small state, an uppermiddle income country as well as the regional average (Table 8.4).

Table 8.3: ICT indicators for St Lucia (2005)

\begin{tabular}{|c|c|c|c|}
\hline & St Lucia & $\begin{array}{l}\text { Latin America } \\
\mathcal{E} \text { Caribbean }\end{array}$ & $\begin{array}{l}\text { Upper-middle } \\
\text { income group }\end{array}$ \\
\hline \multicolumn{4}{|l|}{$\begin{array}{l}\text { Access } \\
\end{array}$} \\
\hline Tel. main lines per 1,000 people & 321 & 177 & 230 \\
\hline International voice traffic (min. per person) & 218 & $\mathrm{~N} / \mathrm{A}$ & 46 \\
\hline Mobile subscribers per 1,000 people & 573 & 439 & 671 \\
\hline Population covered by mobile telephony (\%) & 80 & 90 & $\mathrm{~N} / \mathrm{A}$ \\
\hline Internet users (per 1,000 people) & 339 & 156 & 196 \\
\hline Personal computers (per 1,000 people) & 160 & 88 & 113 \\
\hline \multicolumn{4}{|l|}{ Quality } \\
\hline International internet bandwidth (bits per person) & $95^{*}$ & 161 & 218 \\
\hline \multicolumn{4}{|l|}{ Affordability } \\
\hline Price basket for fixed line (US\$ per month, residential) & 13.9 & 10.0 & 12.1 \\
\hline Price basket for mobile (US\$ per month) & 11.8 & 9.4 & 9.5 \\
\hline Price basket for Internet (US\$ per month) & 22.1 & 25.8 & 17.0 \\
\hline Price of call to United States (US\$ per 3 minutes) & $\mathrm{N} / \mathrm{A}$ & 1.80 & 1.06 \\
\hline
\end{tabular}

Note: * value is for the year 2000; N/A=not available

Source: World Bank (2006b) Information and Communications for Development 2006: Global Trends and Policies. Washington DC: World Bank 
Table 8.4: Governance indicators for St Lucia, 2005

\begin{tabular}{lcccc}
\hline & 2005 & $\begin{array}{c}\text { Upper-middle income } \\
\text { group }(2005)\end{array}$ & $\begin{array}{c}\text { Caribbean } \\
(2005)\end{array}$ & $\begin{array}{c}\text { Small states } \\
(2005)\end{array}$ \\
\hline Political stability & 1.10 & 0.54 & 0.58 & 0.40 \\
Government effectiveness & 1.12 & 0.42 & 0.60 & 0.25 \\
Regulatory quality & 1.14 & 0.53 & 0.57 & 0.27 \\
Rule of law & 0.82 & 0.43 & 0.47 & 0.32 \\
Control of corruption & 1.15 & 0.39 & 0.61 & 0.30 \\
\hline
\end{tabular}

Notes: Units of measures range from about -2.5 to 2.5 , with higher values corresponding to better governance outcomes;

Source: World Bank (2006)

The role played by policy and institutional frameworks differs by sector. The Tourism Incentives Act of 1996 replaced the Hotel Aids Ordinance No. 25 of 1959, and provides incentives (for example, fiscal incentives) to the tourist industry. The Act grants income tax reductions, and customs duty and consumption tax waivers for the importation of supplies, equipment and materials needed for the construction of a hotel. Large hotels pay no taxes and duties for a long period and without any conditionalities, which has led many locally-owned hotels to believe that they are not the main beneficiaries of the Act. The recent budget provides incentives to foreign hotels at the top end of the market only.

The Banking Acts of 1991 and 1993 regulate banking sector activities. Licences are examined by the Ministry of Finance and the Eastern Caribbean Central Bank (ECCB). This does not seem to be particularly constraining and the sector is growing rapidly. In 2001, St Lucia passed offshore banking regulations, but few offshore companies have acquired licences. This is an important finding, which highlights that a concerted effort to develop this sector was not sufficient, probably because St Lucia was too late and not sufficiently competitive to enter this sector.

The regulatory framework for telecommunications has not been favourable for the economy in general. This is because after privatisation of the telecom sector, one firm - Cable and Wireless Ltd (C\&W) - took monopoly control. There is now a regional regulatory authority at the OECS level with regulatory bodies in each country, which made an agreement with the incumbent firm and terminated its monopoly after negotiations. A two-phase transition to a liberalised telecommunications sector began in April 2001. During the first phase, licences were issued to Internet Service Providers (ISPs) and cellular mobile telephone operators. In the second phase, full liberalisation of the sector started and C\&W was issued new non-exclusive operating licences in each of the five OECS states. One of the conditions for the second phase was that the tariffs charged by C\&W had to be rebalanced. As a result of the new regulatory framework, mobile phone charges have decreased by up to 40 per cent due to increased competition between the new entrant Digicel Ltd and the incumbent C\&W. 


\section{External conditions}

St Lucia faces external conditions that affect the development and prospects of its service sectors. Favourable external commercial conditions include growing trends in the demand for tourism services in general and for those provided by St Lucia in particular. However, some external developments are conditioning the growth of the tourism sector as well. For example, air access to St Lucia is expensive. The Caribbean has recently seen a sharp price hike in regional air access, which may adversely affect the number of visitors in the future. Also, the structure of the tourism industry is changing worldwide. Tour operators and travel agencies in developing countries are calculating to become bigger players. This is increasing the competition pressure on local hotels to improve their performance, marketing strategies and health and safety standards.

International trade policies also affect trade in services. St Lucia is facing continuing trade preference erosion, which has already hit the exports of its main commodity bananas - hard. Producers and exporters of agricultural and manufactured products are finding it increasingly difficult to compete with other suppliers, including the larger countries. There are few existing preferences for services, but now that St Lucia is losing its competitive edge due to preference erosion, the promotion of services is suggested as one of the ways forward.

St Lucia is a WTO member and has committed to a few sectors in the General Agreement on Trade in Services (GATS). While it is difficult to assess the precise links with increased investment, in theory appropriate commitments should provide for a more welcoming investment climate. So far, the committed sectors have not enjoyed a large increase in FDI because of GATS. This may be because these sectors were already quite liberalised before making the commitment. However, it is important to consider further commitments, which would show that the government takes the development of its services seriously. For instance, signalling greater openness to foreign education institutions (for example, offshore medical schools) might be helpful in the government's strategy to attract more exporters of education services.

The Caribbean Single Market and Economy includes services, covered by the revised Chaguaramas treaty of 2001 establishing the Caribbean Community: Chapter III on Establishment, Services, Capital and Movement of Community Nationals. The initiative on the free movement of skills originated in the 1989 Grand Anse Declaration (GAD) and found its way into 2001's revised Chaguaramas treaty establishing the Caribbean Community, including the CARICOM single market and economy. Article 45 states that 'Member States commit themselves to the goal of free movement of their nationals within the Community.' Article 46 of the GAD on movement of skilled community nationals states that 'as a first step certain categories of Community nationals should be accorded the right to seek employment in their jurisdictions.' Member states have enacted legislation to implement free movement of university graduates and of artists, media workers, musicians and sports persons from 1995 onwards. There are plans for further liberalisation of movement in other categories. These developments seem to have facilitated the movement of people and hence trade in services. ${ }^{1}$ 


\section{Institutional support structure}

St Lucia is at a critical juncture regarding the level of support and strategic direction it provides to its service industries. Strategic action is important for creating appropriate overall conditions for the development of trade in services. Appropriate public institutions need to have the right mandates and the right interpretation of those mandates. The National Development Corporation (NDC) - the island's principal development agency promoting investment and exports - would need to continue to focus its attention on promoting investment in services, and this needs to go hand in hand with the right incentives and proactive thinking as in the case of goods. Services benefit from appropriate skills, technology institutes, incubators and clustering initiatives, all of which could be implemented and facilitated by the NDC. In particular, it seems important to have a more integral approach to IT parks. The Ministries of Economic Affairs, Economic Planning and of Trade, Industry and Commerce need to co-operate on setting the right framework for the development of service industries and ensure that the objectives of the country and the service sectors coincide.

At the same time, it is important to obtain an adequate private sector representation in order to facilitate good state-business relations for the development of services. The St Lucia Chamber of Commerce is the main voice for the private sector, and it has many (voluntary) members, including some from the services economy. However, just as there is a manufacturers' association, the development of adequate associations to represent services is also important (see Box 8.3 on Barbados).

Box 8.3: Private sector associations in services: Barbados

Barbados is a key example of a small state (in the Caribbean) that has created a coalition of service industries, known as the Barbados Coalition of Service Industries (BCSI). The coalition was formed as a private-sector initiative in 2002 and consisted of 20 member associations initially. However, today it represents the interests of about 39 service associations comprising over 3,000 service providers in the private and public sectors.

The Government of Barbados fully supports the BCSI, providing funding for the secretariat and its projects. The BSCI has an independent board and is tasked to implement an export strategy, by improving the image of service providers and developing their capacity. The BCSI assists its service providers by continuing to educate its members on how to export successfully and on WTO rules. It lobbies government for changes in legislation, provision of incentives and financial assistance; helps service providers to access financial and technical assistance; and it sets up associations where none exist. The BCSI has organised seminars, procurement workshops and launched a website which has proven most valuable for its membership. It also sends out several learning pieces to members on issues such as GATS and external barriers to trade.

In addition, the BCSI is assisting other Caribbean countries such as St Lucia to develop a services coalition. It is envisioned that after national coalitions are formed in individual CARICOM states, they will jointly form a Caribbean Coalition of Service Industries.

Source: Barbados Coalition of Service Industries (http://www.bcsi.org.bb/ [accessed 29 May 2008]) 
Some of the service industries in St Lucia, for example, insurance, banking, tourism/ hotel, engineering and medical services, already have well-organised associations that have been able to voice their concerns to the government successfully. A good example is the Insurance Council, which is mirrored only in Trinidad and Tobago and Barbados in the region. The membership of the Insurance Council has grown gradually over time to around 30 brokers and insurers. Its roles and responsibilities include:

- Communication with government and lobbying;

- Promoting codes of ethics through internal sub-committees;

- Receiving complaints and urging members to address them, thereby improving public trust and confidence;

- Facilitating projects to benefit all members;

- Ensuring the interests of the insurance industry by sitting on committees and boards of other sectors; and

- Imparting information about the insurance industry in educational institutions.

In the tourism sector, the St Lucia Hotel and Tourism Association is well-organised and helps local businesses to promote themselves. For example, the Association assists local hotels that lack adequate IT systems to market their services on the internet. The St Lucia Tourist Board is also supportive. It has offices abroad for international marketing and its budget allocation for further promoting tourism is increasing.

In addition, a host of smaller associations exist in the country, but they often lack the funds to operate strategically and lobby government or to raise the standards of individual members. To fill this gap, a Coalition of Service Industries was formed in 2005. The coalition aims to help set and raise standards and acts as a bureau of standards for the services sector. Discussions are also ongoing about the extent to which the coalition needs to be engaged in advocacy, for example, with respect to skills development in relation to IT parks or other service sectors.

\section{Conclusions}

The contribution of the services sector to the economy is substantial in St Lucia. The development of tourism has succeeded; while initially private-sector led, the government had the vision to provide the right framework for the development of tourism services.

In other instances, for example, in offshore banking services, government action failed to lead the sector into success, because the external environment was not right. This is a painful reminder that government interventions, if they are to be successful, need to be well thought out and all factors (domestic capabilities, regulatory frameworks and external conditions) need to be enabling. 
In this regard, St Lucia is at a crucial juncture. In order to move beyond tourism services and promote exports of other services, it needs to move more strategically into certain key sectors (see Box 8.4 on the private sector's view towards adopting an integrated approach in this regard).

Box 8.4: An integrated approach to developing services: a private sector view

The government needs to co-ordinate action to support services. There are clear co-ordination failures that justify government involvement, such as a dearth of entrepreneurial people, high unemployment and social dislocation. An integrated approach is needed to move out of this situation, which would include:

- Provision of research know-how;

- Improving the culture of training;

- Identifying needs for infrastructure;

- Improving the entrepreneurial spirit;

- Improving access to credit; and

- Emphasising positive public action rather than incentives (which could be used as an excuse for failure in other areas).

Source: Interviews in St Lucia

IT-related activities are a prime candidate for further development. The fact that there are already some IT-enabled service exporters, coupled with a relatively well-organised finance and insurance sector suggests that the current interest in IT parks could be successful if supported by a well-educated and trained workforce, IT infrastructure, research centres, appropriate incentives and international promotion of the sector (including in trade agreements).

Another promising service sector for St Lucia relates to offshore medical schools and training of nurses. There are already some offshore medical schools in the country, which provide a foundation for developing this sector further.

\section{Note}

1. Source: Based on interviews conducted in St Lucia. 